\title{
Geo-Political Structure and Integration Strategies in Nigeria since Independence: A Critique
}

\author{
ADEFILA, J. O. (PhD) (Corresponding Author) \\ Department of Geography, Ahmadu Bello University, Zaria \\ Tel: +234 803830 9791, E-Mail: olufiladr@yahoo.com
}

Received: May 02, 2012 Accepted: May 20, 2012 DOI: 10.5296/jpag.v2i2.1840

\begin{abstract}
It becomes obvious that the critical problem of the governments in Nigeria is centred on how to sustain and maintain the territorial integrity of the country since we attained independence in 1960. The problem is traceable to the ethno-pluralistic and socio-cultural diversities among the various components that constitute the federal state. The British administration had profound influence on spatial imbalance and dualistic pace of the economy such that the country is polarized into poor rural, agricultural, disadvantaged on the one hand and urban, affluent, industrial and commercial on the other. The paper aimed at assessing the measures being adopted by successive governments in Nigeria towards national integration and stability in the midst of tribal, religious, and cultural differences. One made use of secondary information from official gazettes, journals, national dailies, literatures and research works. It was discovered that integrative measures such as adopting federal system of government, the issue of federal character, establishment of National Youth Service Corps (NYSC), and creation of more States and local governments have not yielded much improvements and achievement of maintaining unity, peace and progress. Instead, there has been political violence, ethnic clash, religious intolerance, civil unrests, armed robbery, leading to insecurity of life and properties. On this note, one recommends among other things an advocacy for holding national conference or referendum where rightful thinking stakeholders, elder-statesmen, political leaders and trade unions would put heads together and champion a new course for Nigeria to progress. Moreover, there should be social justice in the distribution and allocation of national resources to regions in the country without discrimination either on the ground of political, religious or tribal affiliations. The derivative principle should be strictly adhered to, such that wealth and mineral producing areas should have proportionate share of the national income. Finally, we should sink all differences in the country and allow democratic government to reign supreme in order to make Nigeria takes her rightful position in the world.
\end{abstract}

Keywords: Nigeria, Geography, Political, Structure, Integration, Strategies, Independence 


\section{Introduction}

Perhaps the most difficult task before successive governments in Nigeria since independence was centred on the national question of political stability, cohesion and integration. The problems are well-rooted in the various ethnic groupings of diverse origin that were married together and constituted the Federal Republic of Nigeria. The first military coup on January 15, 1966 and other counter-coups that followed; the political crises of 1964 in the defunct western region; the armed struggle against the secessionist of the Igbos tagged 'Republic of Biafra war' (1967-1970); the official cancellation of the 1973 National census results; the popular annulment of the Presidential election of the June 12, 1993; the political unrest and many other tribal and religious conflicts in the country explain the untold hardships involved and governments continue in the struggle to secure national unity, peace and stability.

The subsequent balkanization of the country into manageable political units and continued agitation for the creation of states and local governments aimed at reducing tribal and ethnic conflicts among regions. At the centre stage, the idea of 'federal character' was introduced into the appointment of persons into the public service, and admission of students into higher institutions. The contributory forces towards national integration were multi-dimensional in terms of the country's peculiar socio-cultural and economic dualism having historical origin (Echezona, 1997). In other words, the issue of national integration and the challenges confronting Nigeria as corporate entity has been a long standing one.

This paper attempted to unfold the issues involved in Nigeria's unity and disintegrative forces and efforts being made by various governments to sustain the corporate existence of this giant nation.

\section{Emergence of Nigeria as a Nation}

The history of pre-colonial empires in Africa south of the Sahara showed that Nigeria was originally constituted with many empires. Eluwa (1988) highlighted the ancient empires in Nigeria to include Kanem-Bornu that confined to the north-east of Lake Chad; the Hausa-Filani occupying the northern region; the Jukun Kingdom of the middle Benue region; the Nupe Kingdom around Niger-Kaduna confluence; the Edo empire of Benin; the Oyo empire of the Yoruba land in the former Western region; the Igbos in the eastern region, the Ijaws of the Delta; the Ibiobios of the Cross-river; the Urhobo community; and the Itsekiri Kingdom in the western Delta. These empires and kingdoms were powerful possessing a regularized traditional pattern of administration ever before the intrusion of the British on the Nigerian soil. Mohammed (1998) remarked that over 394 ethnic groupings with different historical origins, dialects, cultures, languages with variations in the level of social and political attainment were confined within Nigeria's territorial space.

Perhaps it could be rightly said that Nigeria was born in 1914 sequel to the amalgamation of the Northern and Southern Protectorates thereby putting the country under one colonial administration. Indeed, the emergent geo-political entity that we refer to as 'Nigeria' today is the handwork of the British administration. The amalgamation exercise was viewed with 
seriousness that it contributed to the genesis of socio-political problems in the country. Why? This is true to a large extent because it did not take cognisance of the administrative convenience of the people having diverse multi-ethnic origins.

\section{Geo-Political Issues and Nigeria's Stability and Integration}

A dominant feature of Nigeria is her sheer geographical size and multi-ethnic diversities coupled with a large population of 140 million (NPC, 2006) that are unevenly distributed over a national territorial space of about $923,770 \mathrm{Sq}$. Km consisting of 36 states including Federal Capital Territory (FCT) Abuja as planning region. The federal system of government was considered suitable for Nigeria by the British colonial administration and after independence the country continues to protect and sustain her territorial integrity in the midst of socio-economic and political uncertainties. Indeed, up till present, the country is operating under a delicate balance between the various administrative units and the centre.

Parallel to population heterogeneity is the variations in her physiographic and ecological features. One can readily identify the forest vegetation in the south and open grassland in the north. This bio-physical configuration reflects the climatic variations in the country. Indeed, rainfall totals decreases from south to the north. While some coastal areas experience about 360 rainy days, the extreme north has less than 90 rainy days. This spatial pattern of rainfall distribution also affect agricultural production which favours the planting of industrial tree crops such as cocoa, coffee, rubber and palm produce in the south and subsistence grain crops such as maize, guinea corn, cow-pea and millet in the north. The two contrasting ecological zones are seen to be complementary. Indeed, the country is well-endowed with adequate natural and human resources that are capable of sustaining the teeming population and secure a viable nation with machinery for its internal and external control (World Bank, 1997). But in the presence of ineffective and weak development of infrastructural facilities, one considers the country too large to be governed directly from Abuja without marked antagonisms among various geo-ethnic diversities that are located in remote areas away from the centre.

The creation of States and local government areas have laudable goals of correcting regional imbalance in socio-economic development (Adefila, 2008) and more importantly, it gives room for popular participation at the community level (Balogun, 2000). However, in the process based on different geographical sizes administrative units were created and demarcated without considerations for socio-cultural homogeneity (Otite, 1990). This singular factor has aggravated conflicts among diverse population groups culminating in favouritism, victimization and regional inequalities. The disparities became glaring in the percentages of the population, number, size of local governments and electoral wards that were approved for most States in the country. Nnoh (1998) highlighted some of the anomalies to include the arbitrary merging of some economically diverse Igala, Ebira and Okun-Yoruba into the present Kogi State; the occasional confrontation between Urhobo, Itsekiri in Delta State and Tivs and Jukuns in Taraba State were not unconnected with the same problem. In addition, by pronouncing Asaba as part of and Capital of the new Delta State is seriously 
viewed as an exercise in nepotism and abuse of power. In Kwara State, (Aluko, 2000) observed that the creation of four new local governments from Ilorin Emirate and splitting the former Oyun local government area into two namely, Offa and Oyun leaving the other geographically large local governments such as Edu and Ifelodun local governments intact is regarded as favouritism. Akpan (2000) remarked that re-structuring of political units arbitrarily without cognisance to cultural origin can widen the spatial inequalities among the regions.

There is the issue of socio-cultural pluralism in this country. The distribution and homogeneity of cultural attributes such as ethnic, kinship, relation, languages and tradition are intimately related to the problem of political integration, stability and cohesion. The uneven spatial spread of such cultural attributes is dangerous to national stability. It should be noted that out of the numerous ethnic groups in Nigeria, the constitution of the Federal Republic of Nigeria recognized three major tribes namely, Hausa to the north, Igbos to the east and Yorubas to the west thereby designating other tribes as 'minorities' In effect, fear has always been expressed by the so-called minorities of domination by the larger groups hence, continued struggle for seizing power at the centre.

The issue of religious pluralism has been a sensitive aspect of our political life and constitute a potent centrifugal force among ethnic groups in Nigeria. Both religion and tribalism have combined effects on the political climate in this country (Asolo, 1997). There are many traditional religions in different ethnic groups but their faithful had been marginalized into two major religions namely, Christianity that reign supreme in the south and Islamic religion dominating the north. There have always been religious conflicts among the religious groups inspite of the fact that the federal constitution declares Nigeria has a secular State.

One can readily identify yet another issue that has continued to run-counter to Nigeria's efforts towards political stability and effective integration and it relates to the politics of revenue sharing formula. The problem has been how to allocate national resources in an equitable manner so as to enhance a balanced development among component units. Indeed, the exploitation and distribution are considerably influenced by the government in power. In this case, religion, ethnicity, cultures and sectional political interests have combined effects on government decisions on revenue allocation and exploitation of minerals in the country. In effect, the limited and scarce financial resources in the country were being utilized to develop regions of interest thereby leaving the producing areas of the resource deprived and neglected. This problem of resource control led to the oil producing States uprising and the uncompromising posture of the Ogoni people. Saro-Wiwa (1994) argued that petroleum is exploited by the federal government from their territories only to be appropriated by other Nigerian communities and argued that the principle of derivation should be the criterion for revenue allocation and moreover, a confederal system of government be adopted as a means of ensuring a measure of resource control over their lands. In the process, the Ogoni leader was killed by the military government in power but there was a resurgence of the agitation during civilian administration in 2009 that granted the affected people amnesty. 


\section{Strategies towards National Stability and Integration}

In attempt to maintain the corporate existence, peace and stability in Nigeria, the successive governments have adopted series of integrative measures geared towards achieving unity in our diversity. Some of the strategies include the adoption of federalism as a system of government, the introduction of National Youth Service Corps (NYSC), the federal character, constitutionalism and creation of States and local government areas. The strategies are discussed below.

\subsection{Federal System of Government}

Adigwe (1978) defined a federal state as an association of states formed voluntarily for certain purposes in which the component units are ideally independent but coordinate with one another. It is essentially for maintaining unity in the midst of diversity. Federalism was established through the Lyttleton constitution in 1954. The constitution recognized three regions namely, the north, east and south with a powerful centre. Having realised the multi-ethnic composition of Nigeria, the British administration established this federal system of government. Babangida (1994) remarked that the system was found most suitable for holding together people with different origins, cultures, languages, political institutions and safeguarding the identity and separate existence of the component units that form the federation. Indeed, this formed the first practical approach to address the problem of national integration and stability. The constitution of the Republic of Nigeria 1999 with amendments in 2011 emphasized that 'Nigeria shall be a Federation consisting of states and a Federal Capital Territory'. The legislative power was shared between the federal and state legislatures. It made provision for both exclusive legislative lists (Second schedule section II) and the concurrent legislative list (Second schedule section III). While the exclusive list specified items over which the federal legislature was vested with exclusive legislative competence, the concurrent list catalogued the items over which both the federal and state legislatures had legislative competence. To resolve conflicts between the federal and the state laws, it was provided that 'if any law enacted by the House of Assembly of a State is inconsistent with any law validity made by the National Assembly, the law made by the National Assembly shall prevail, and that other law shall to the extent of the inconsistency be void' (Nigeria constitution, 1999).

\subsection{Creation of States and Local Governments}

The initial three regions namely, north, east and west were discovered to be inadequate and the fourth region that is, mid-west region was created in 1964. Following continued agitation for more states by the tribes that felt marginalized, the Gown administration created a twelve-state political structure. In 1976, the country was broken into 19 states and in 1989, Babangida administration created addition two states thereby making a total of 21 states. In 1991, additional nine states were created to make a total of 30 states in the federation. In 1996 under the military administration of General Abacha, additional six states were created and altogether make 36 States including FCT Abuja, the planning region of the federal government of Nigeria. The cardinal objective of creating more states is to satisfy the 
yearnings and aspiration of minorities who felt to cheated, marginalized, and deprived of their share of benefits from economic growth and development. Omoleke (2000) stated that the creation of more local government was to bring government closer to the people at the grassroot and give local communities opportunity to partake in decision-making process. This view was corroborated by (Oyuji, 2000) that advocated for decentralizing the power in favour of local participation in governance. Indeed, the overall objective of the government was to bring about a balanced development having realized the spatial inequalities among the units that make up the country. But it is a pity that the more the creation of states and local governments the more it aggravates the problem of the nation's diversities.

\subsection{Federal Character}

The idea of federal character emanated from the constitution drafting committee (CDC) that was inaugurated by the Late General Murtala Mohammed in October, 1975. According to the committee, federal character refers to 'distinctive desire of the people of Nigeria to promote national unity, foster national loyalty and give every citizen of Nigeria a sense of belonging to the nation notwithstanding the diversities of ethnic origin, culture, language or religion which may exist and which it is their desire to nourish, harness to the enrichment of the Federal Republic of Nigeria' (Report of the CDC Vol. 1:1977). As a strategy for national cohesion (Ofigbo, 1997) remarked that the federal character is expected to ensure fair play in the appointment of persons to high ranking government establishments and parastatals without discrimination of any kind. It is to ensure a broad public participation in the country's affair as well as fostering even development. While the principle of federal character has been fully entrenched in the constitution, the application of the principle remained problematic because of the disparity in the standard of western education attained among the states in the federation (Mohammed, 1998). Often a times, appointments are given to mediocre under the umbrella of belonging to less-privileged and educationally backward areas and this is the major drawback of the principle which does not help Nigeria to progress as a nation.

\subsection{The National Youth Service Corps (NYSC) Scheme}

This laudable programme was established by the federal military government in 1973 through Decree No. 24 under the Major General Yakubu Gowon's administration. It is designed for graduates of universities and other higher educational institutions (HEIs) both within and outside Nigeria. The cardinal objectives of the scheme are: to develop common ties among them and promote national unity by ensuring that as far as possible youths are assigned to jobs in states other than their states of origin and that youths are exposed to the mode of living of the people in different parts of the country with a view to removing prejudices, eliminating ignorance and confirming at first hand the many similarities among Nigerians of all ethnic groups (NYSC Decree, 1973). The expectation is that such exposure would assist the corps members to cultivate a tolerant attitude towards Nigerians from other cultural and ethnic backgrounds. But be as it may seem, such a laudable scheme could not achieve the desired goal of national integration because coppers do refuse distant postings that are remote such as rural areas. In addition, there is the problem of alienation of the corps members when 
it comes to securing permanent appointments. Of recent, the killings of youth corps members during the April, 2011 general elections as electoral officers made Nigerians to express bad feelings against the scheme since life and properties of the serving corps members cannot be guaranteed in their respective place of postings hence, it is either scrapped or regionalized so as to give peace a chance.

\subsection{Constitutionalism}

The governance of a people according to the provisions of a framework of rules and regulations is often referred to as constitutionalism (Adigwe, 1978). One would like to refer to a particular section of the Federal Republic of Nigeria's Constitution of 1999, No. 24 and with amendments in (Constitution of Nigeria, 2011) especially the section that enforces the principle of national stability and integration. The constitution in question emphasized Nigeria 'as one indivisible and indissoluble sovereign state to be known by the name of the Federal Republic of Nigeria. It went further to say categorically that 'Nigeria shall be a federation consisting of states and a Federal capital Territory'. The constitution stated that 'if any other law is inconsistent with the provisions of this constitution, this constitution shall prevail, and that other law shall to the extent of the inconsistency be void' (Nigeria Constitution, 1999). This quotation shows the supremacy of the constitution. This is a true indication that all the disintegrative and other centrifugal forces put together cannot divide Nigeria.

In a bid to keep the territorial integrity of this country intact, the Federal Military Government declared war against the Eastern Block, a civil war led by Lt. Col. Odumegwu Ojukwu who proclaimed the Igbo region as a 'Republic of Biafra' in 1967. Ojiako (1979) reported that 'on May 30, 1967, Lt. Col. Ojukwu in a early morning broadcast from Enugu proclaimed the Independent Republic of Biafra on the ground that the people from eastern Nigeria believed that they could no longer be protected in their lives and properties'. This broadcast marked the genesis of a civil war between the Federal Military Government and the Igbos in the defunct eastern region. The civil war that lasted for three years (1967-1970) took a heavy toll on the socio-economic development, loss of lives and properties and rendered millions lamed.

\section{Recommendations}

It is obvious that Nigeria has been confronted with the problem of binding the political units to the centre partly on the ground of her large geographical size, spatial inequalities, unprecedented population growth and multi-ethnic pluralism. The situation tends to undermine the spirit of federalism as entrenched in the constitution. The problem is difficult to tackle but certainly not impossible to overcome. One is of the opinion that it is high time Nigerians put heads together and champion the way forward by holding a National conference or referendum in which all stakeholders, elder statesmen and political leaders representing each of the States in the federation.

Indeed, the issue of federal and confederal systems of government should be revisited. The 
British administration that introduced federal constitution knew that the system was on experimentation and trying to see the extent to which it can work in the midst of numerous diversities. Having tried federalism for these years resulting in robbery attacks, political violence, ethnic clash, religious intolerance, and risk of lives and properties, we need to give consideration for confederal system of government that advocates for politically strong regional States with a loose centre. Essentially, the concentration of political power at the centre prompted all sections of the country to be recognized at the centre in order to seize power and gained control over national resources. If the power centre becomes less attractive it will discourage agitation of all sorts across the country.

The contrasting ecological zones being identified in the country namely open grassland to the north and forest vegetation in the south arising from spatial variations in climate, soil and natural resource endowment should be allowed to promote inter-regional trade. The two regions are complementary and as such north-south trade alignment should be strengthened. Parallel to this is the construction of road networks and railways to link the west and the east together. It would in no doubt facilitate accessibility and foster socio-economic intercourse among the peoples in this country. The Umoru Yara'dua and Jonathan seven-point agenda should be pursued with all seriousness in order to move the country forward.

In history, one of the reasons why there are military interventions into Nigeria's body politics was to maintain law and order. After independence, the military junta has ruled the country for a long period of time without giving room for a democratically elected civilian administration and the end result did not give a better performance in governance. Credence should be given to General Olusegun Obasanjo who relinquished power to democratically elected government thereby disengaged the military administration in May, 1999. One would suggest that an international treaty should be signed that would preclude any form of military from assuming power in any country globally. In essence, democracy must be sustained at all costs if only if, the county will move forward and take her rightful position in the world.

On issues affecting revenue allocation and sharing formula, we need to be realistic and borrow ideas from other countries in the world. Regions that are producing minerals, export products and industrial raw materials should be given a proportionate share of the national income. Successive governments in Nigeria had failed to recognize the contributions of the oil producing areas which culminated in human killings and civil unrests. The federal government was commended for taking bold step by granting amnesty to the affected regions but government should go further by adopting principle of derivation and social justice in the allocation and distribution of the national resources. By so doing, it guarantees peace, unity and progress in the country.

\section{Conclusion}

This paper attempted to cross-examine the origin of Nigeria as a nation and political entity bearing in mind the external influence of the British administration on the geo-political structure and the attendant problems of maintaining peace, unity and stability in a multi-ethnic and pluralistic society. 
In most respects, Nigeria could be paradoxically presented as being rich but whose people are suffering from deprivation, socio-economic neglect and varying degrees of inequality. The country is rich in land, human, oil and natural resources (World Bank, 1997). If more of the wealth had been channelled to the development of the generality of the people and to the productive use of land and other resources then, Nigeria could be adjudged to possess a bright and promising future.

The way and manner in which governments address the socio-economic and ethno-political problems largely determine the fate of Nigerians and have a major impact on the degree of success and failure of the various levels of administrative units in the country. We have not able to satisfactorily address the issue of how economic growth could spread spatially in order to maintain a balanced development. The religious, political, civil unrest, armed robbery, insecurity of life and properties in the country could be attributed to ineffective leadership. Indeed, Nigeria needs visionary, courageous, radical and pragmatic leader who can take the bull by the horn. But a tree cannot make a forest. The subordinates must develop team spirit, transparent and accountable for all their activities.

By and large, until Nigerians see ourselves as brothers and sisters of the same blood and sink all the differences for a common goal of promoting unity, peace and progress, the dream of taking the rightful position among the first twenty countries in the world in the year 2020 will remain a mirage.

\section{References}

Adefila, J. O. (2008). Pattern of development in Plateau State: An inter-local government analysis for planning. Journal of Environmental Research and Policies. Duncan Science publication. Calabar. 3(3):101-106

Adigwe, F. (1978). Essentials of government for West Africa. Ibadan. Oxford University press. Pp. $17-20$

Akpan, P. A. (2000). Spatial inequalities in Nigerian development: The case of Akwa-Ibom State. African Journal of development studies. 2:78-86

Aluko, M. A. O. (2000). Corruption and Nigerian development: A sociological perspective. African Journal of social and policy studies.

Asolo, A. A. (1997). Fundamentals of development administration: A developing country perspective. Ibadan IBDL educational publications.

Babangida, I. B. (1994). Federalism and Nation building in Nigeria: The challenges of the twenty-first century. Nigerian Journal of federalism. 1(1):7

Balogun, M. J. (2000). The scope for popular participation in decentralization towards a new paradigm of centre-periphery relations. United Nations centre for regional development. 2(1):153-173 
Constitution Drafting Committee (CDC). 1977. Vol. 1. Lagos.

Constitution of the Federal Republic of Nigeria (1999). Amendments (2011). Government printer. Abuja.

Echezona, N. (1997). Strategies for national integration. In Olugbemi, S. O. (eds). Alternative political future for Nigeria. Lagos. Publication of the Nigerian political science association.

Eluwa, G. I. C. (1998). A history of Nigeria for schools and colleges. Onitsha. African FEB publishers

Mohammed, M. N. (1998). Ethnicity and national integration: The Nigerian experience. Ilorin Journal of Arts and Social Sciences. Ilorin. Nathadex publishers.

National Youth Service Corps (NYSC) decree 1973. Acts and amendments. Supplement to Official gazette extraordinary. 60(28)

Nnoh, O. (1998). Ethnic politics in Nigeria. Fourth edition. Enugu. Publishing.

Ofigbo, A. I. (1987). Federal character: Its meaning and history. In Ukwu, I Ukwu (eds). Federal character and national integration in Nigeria. Jos. Salama press.

Omoleke, I. I. (2000). Planning with the grassroots: A socio economic development strategy. African Journal of social and policy studies. A biannual collection of recent scholarly contribution development African consortium. 1:1

Ojiako, J. O. (1979). 13-year of military rule' (1966-1979). Lagos. Daily Times publication.

Otite, O. (1990). Ethnic pluralism and ethnicity in Nigeria. Ibadan. Chameson press.

Oyugi, W. O. (2000). Decentralization for good governance and development: The unending debate. Regional development dialogue (RDD). United Nations centre for regional development. Nagoya. Japan. 21(1):3-21

Saro-Wiwa Ken (1994). Oil and issues at stake. Guardian News papers. April. P. 7

World Bank (1997). African development indicator. Wahington.

Zolberg, A. R. (1997). Patterns of national integration. Journal of modern African Studies. 5(4):449-50 